\title{
Pension reform: The Swedish case
}

Received: 2nd July, 2001

\section{Lars Hörngren}

is Chief Economist at the Swedish National Debt Office. He has a PhD from the Stockholm School of Economics, where he has also held a position as assistant professor of financial economics. Prior to joining the Debt Office in 1996, Hörngren was Senior Advisor to the Governor at Sveriges Riksbank. He is also a member of the board of the Swedish Financial Supervisory Authority.

\begin{abstract}
This paper presents the main features of the new Swedish public pension system, the motivation behind the reform, and its implications for public finances. The conclusion is that by addressing the imbalances and inefficiencies in the old system at an early stage, Sweden is better equipped to handle the demographic transition over the coming decades. The country now has a financially independent and financially stable public pension system. Since the reform is based on a broad agreement in the parliament, it should also be politically robust, another essential feature of a public pension system.
\end{abstract}

Keywords: public pension systems; pay-as-you-go pension systems; pension reform

\section{Introduction}

Sweden is in the same situation as most other industrialised countries: over the coming decades an ageing population will put strains on social security systems in general and public pensions systems in particular. To some extent these tensions are unavoidable. For example, the economy will have to adjust to a shrinking labour force, in relative and, perhaps, even absolute terms. The transition problems are exacerbated, however, by the fact that Sweden, and many other countries, have under-funded or even unfunded public pension systems.

What distinguishes Sweden in this context is that it has made substantial and, in some respects, radical changes in the public pension system before the problems have become visible. The new model is a compromise, as the decision makers had to consider commitments made under the old pay-as-you-go system. However, the reform has given Sweden a pension system that is far better able to cope with the challenges facing public pension systems in the decades to come. In the process, it has also improved the prospect for Sweden's public finances.

What stands out in the Swedish reform process is also the commitment and unity displayed by the political system. Based on the shared perception that reform was necessary, five political parties, representing 80 per cent of the current parliament and bridging the traditional divide in Swedish politics, have been able to agree on far-reaching reforms. In effect, Sweden has for the past ten years had a partial coalition government in matters related to the pension system. This means that the reform should be able to survive future changes in the majority situation in the parliament. This is an essential characteristic of a stable pension system, 
of course, since it allows people to plan for retirement with a reasonable degree of certainty.

The paper starts with a review of why a reform of the Swedish public pension system was necessary. It then describes the main features of the new pension system. Finally, the implications of the reform for public finances and the central government budget are discussed.

\section{Why Sweden needed a new pension system}

Sweden introduced a public general old-age pension scheme in 1914. In 1960 it was complemented by a compulsory income-related supplementary pension system, based on the pay-as-you-go principle. One aim was to raise the standard of living for the elderly as soon as possible. This meant that the first generation affected by the system received benefits in excess of their own contribution. In order to compensate for the expected drop in private savings, more funds than needed for current expenditures were raised and deposited in the National Pension Fund (the AP Fund).

This system seemed to work well for the first 25 years or so, but gradually it became clear that reforms were needed. The system was conditioned on growth assumptions that had proved unrealistic. As a result, some decades into the $21 \mathrm{st}$ century the costs of the pension system would have required drastic tax increases and possibly also cutbacks of other expenditures. That would have put the working generation and the rest of the public sector in an impossible situation. Neither the social security ambitions, nor targets of sustainable public finances can be fulfilled in such circumstances.

The demographics working against unfunded pension systems over the coming decades are general and well known. However, as important for putting such systems under strain is the fact that they typically are highly non-actuarial, in the sense that the links between the individual's contributions to the system and his benefits in the form of future pension rights are weak. In the Swedish case, contributions were based on total income (via a payroll tax). Pensions rights, on the other hand, were based on the so-called $15 / 30$ rule. This meant that a person had to have at least some income during 30 years or more to be entitled to full supplementary pension. The level of that pension was determined by the average income during the 15 years when the person's income was the highest. This rule discouraged labour force participation and, as importantly, meant that contributions from the individual's point of view during a large part of the working life could be seen as a tax. When such a non-actuarial system is faced with a demographic shift or other strains, taxes have to be raised to levels that are politically and economically unacceptable.

It is simple to introduce pay-as-you-go systems, since the main beneficiaries are in the current generation, which gets higher pensions without having to make a transfer to a previous generation. What makes reform difficult is that the mechanism works in reverse if one wants to get rid of such a system: one generation will have to pay for both their parents' and their own retirement.

A shift to a fully funded system was never seriously contemplated in Sweden. This was deemed too drastic a reform. Instead, the aim has been to change the pay-as-you-go system to make it more financially stable. At the same time, the ambition has been to make the system financially independent of the state budget. Conversely, this makes the budget independent of the pension 


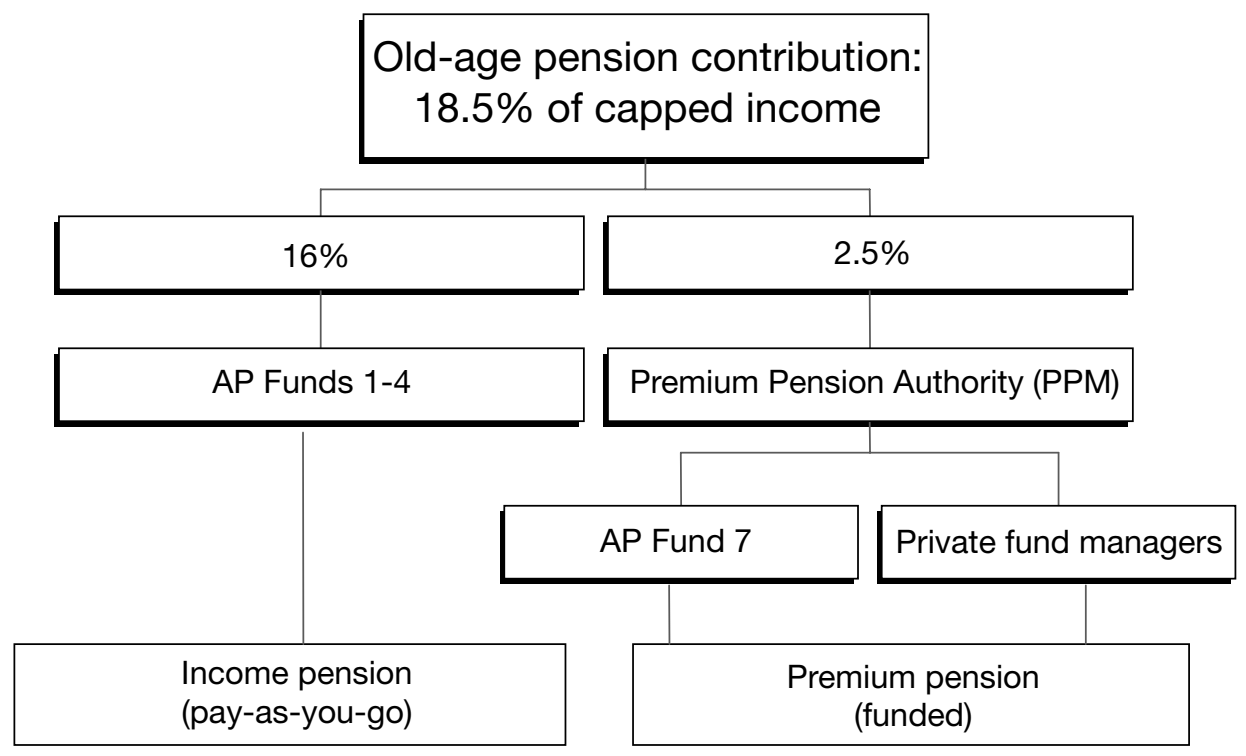

Figure 1: The structure of the new pension system

system, also in the sense that the state does not have a claim on the assets reserved for future pensions.

To come up with a solution meeting these objectives has required a lot of compromising and ingenuity. The reform process has taken more than 15 years, from the appointment of the first review committee to the final decisions in the parliament. The detailed rules of the system are complex, but it is possible to summarise the basic features.

\section{Basic features of the new pension system}

The new system is still predominantly based on pay-as-you-go principles. However, it also has a funded part. A sum corresponding to 18.5 per cent of wage income (up to a certain level) is paid to the pension system. ${ }^{1}$ Of this, 16 percentage points go into the pay-as-you-go system, which gives the individual an income pension. The remaining 2.5 percentage points go into a funded system and give a premium pension. The outline of the system is presented in Figure $1 .^{2}$

\section{The income pension}

The new pay-as-you-go system is based on actuarial principles. This means that each individual's pension rights are based on his lifetime earnings, ie, the disincentives of the $15 / 30$ rule have been eliminated. A notional account is created for each individual in which pension rights are accumulated. The balance on the account is affected by wage income (and some other factors) and a notional interest payment is credit to the account each year. The interest rate is based on the growth of the average wage rate in society. Consequently, it works like a notional defined contribution system with a link between average wage developments and pension rights.

The pay-as-you-go system is built around four buffer funds, AP Funds 1-4, which are run as government agencies. They each receive one quarter of the pension fees and one quarter of the 
income pension payments is taken from each fund. The new buffer funds have been created from the National Pension Fund established in the old system, but now the funds' assets are committed to future pension payments.

The funds are responsible for the management of the assets of the pension system. Their objective is to manage the assets so as to maximise the benefits to the income pension system. It is also stipulated that the risk level in the funds should be low in the sense that the funds shall try to match the pension liabilities against which the assets have been set aside. Within these risk limits, the task is to achieve a sustainable high return.

The buffer funds have broad investment rules laid down in law, allowing investments in domestic and foreign equities and bonds. There is a 70 per cent cap on equity holdings and a 40 per cent limit on the amount of foreign exchange exposure, but in general the rules are similar to those of private pension funds. Within these limits, the task to define benchmark portfolios has been delegated to the individual funds. ${ }^{3}$

One reason for creating four funds with identical rules and tasks is that this puts the funds' managers in a competitive position, which should improve performance. Moreover, as the funds assets are significant in relation to the domestic capital market, it was deemed important to avoid undue concentration of ownership. The funds' ability to diversify internationally also limits this concern.

Upon retirement, which is possible when a person reaches the age of 61 , the total assets in the notional account (after adjustment for a notional future growth rate set at 1.6 per cent per year) are divided by the expected number of years in retirement for that person. Thus, people retiring early get a smaller annual pension. The average life expectancy is set for each cohort when it reaches the age of 65 . This means that an expected increase in average lifetime reduces the annual pension for all persons entering retirement. This makes the system more resilient to foreseen demographic changes. Since pensions are set at retirement, they are not affected by unexpected changes in actual average lifetime for a cohort in retirement. There is a survivor bonus, going to members of a cohort living longer than average.

One important effect of the reform is to reduce the tax wedge; each krona of labour income now contributes to the future pension. The system is not fully actuarial, however. First, just like in the old system, there is a cap on the annual pension rights, but no cap on the payroll tax. For people with incomes exceeding SEK280,000 per year (roughly $£_{20,000)}$, there is thus still a tax wedge. However, it is explicitly billed as a tax and the revenues go into the state budget like any other tax.

Secondly, pensions rights are awarded for certain activities outside the labour market, eg, time spent caring for young children, military service, and studies. In these cases, the state budget pays the contributions to the buffer funds.

Thirdly, there is a guaranteed pension paid out regardless of income, based solely on a residency requirement and funded directly over the state budget. The guaranteed pension is reduced one to one as a person's income pension rises. This limits the marginal benefit of labour force participation, in particular for people with low incomes.

Despite these non-actuarial features, typically reflecting trade-offs between efficiency and social policy goals, the new system is considerably more fair (in 
an actuarial sense) and provides stronger incentives for labour force participation than the old one. The latter is important since it may help to counteract the effects of a shrinking population. This is important in itself, but it should also increase the income base of the pension system during the demographic transition.

\section{The premium pension}

The funded part, into which the remaining 2.5 per cent of wage income goes, is called the premium pension. It is also administered by the government through a newly created agency, the Premium Pension Authority (PPM). ${ }^{4}$ However, the individual decides how his funds are allocated and private fund managers manage the funds. There are close to 500 mutual funds registered with PPM, many of which are run by foreign fund managers. The basic requirement for a fund to be registered in the system is that it adheres to UCITS rules. Thus, it is possible to invest freely in foreign assets. Savers can divide their assets between at most five funds at each point in time and can change funds freely (using the telephone or the Internet). For those failing to choose - or actively deciding not to choose - funds, the state has set up a default fund, the Seventh AP Fund. ${ }^{5}$

At retirement, the individual can use his funds to buy an annuity (with profit) or let the assets stay in the funds and get his pension in the form of an income draw down. The pension derived from the funded part depends exclusively on the value of each person's investment, ie, the financial risks are borne entirely by the individual. Over time, there may thus be substantial differences in the pensions received by individuals with the same earnings during their working years due to their choices of funds.

\section{The financial stability of the pay-as-you-go system}

The premium pension is inherently stable, like any unit-linked scheme, since by definition claims equal assets. The income pension derived from the pay-as-you-go system, on the other hand, is by definition not fully funded. Instead, the payments to and from the system are channelled via the buffer funds. The initial level of the buffer funds has been set so as to create reasonable certainty about the sustainability of the system, ie, the initial assets together with the expected future income stream should be sufficient to cover expected future pension obligations. Many analyses have been made to calibrate the system appropriately. However, it goes without saying that it is hard to predict with precision what will happen to a pension system covering pension rights extending over several decades. In the Swedish system, there are three main sources of uncertainty:

- The interest rate in the system, related to the average income, may be higher than the growth rate of the income base, which is related to the total wage sum.

- The assumptions about expected average lifetime, although adjusted for each cohort entering retirement, may prove wrong.

- The return on the assets of the buffer funds may be lower than projected.

The first factor is related to a political decision in the design of the new system; the living standard of the retired shall be linked to the average living standard of the working population. This will put a strain on the system if the working population shrinks and if the amount of work per person falls. Since it is quite possible that average incomes will rise in 
a situation with a diminishing labour supply, the growth paths of pension rights and incomes to the system may tend to deviate more and more. This was deemed a risk worth taking, however, in order to fulfill the social ambitions of the public pension system.

The second factor is also related to demographic uncertainty, but of a more general nature, as it is faced by any pension system where annuities are set at retirement. The financial uncertainty is also quite general, as it arises in any pension system where benefits are defined.

In the old system, the pension rights were backed by the state. Any shortfall would have had to be covered by expenditures over the central government budget. The new system is financially independent and will have to make do with 16 per cent of the wage sum. Consequently, it has been necessary to design a mechanism that allows the pay-as-you-go system to cope with financial strains, irrespective of their origin. This has led to the construction of the so-called automatic balancing mechanism, popularly known as the brake. The details of this mechanism are quite complex, but the basic logic is simple and intuitive.

The financial position of the system is expressed (once a year) by a balancing ratio. It measures the current ratio between the assets of the system and its liabilities. The assets consist of the net present value of projected future pension contributions and the market value of the buffer funds. On the liability side is the current value of pension rights. If the balancing ratio falls below unity, the system has a deficit. If such a situation prevails, the buffer funds would gradually be exhausted and, at some point, pensions would have to be cut drastically, with unacceptable social consequences.

The counteracting mechanism is that the interest rate in the system will be multiplied by the balancing ratio as soon as the latter falls below unity, slowing down the accumulation of liabilities. The brake will also affect pensions in the payout phase, ie, it slows down the outflows from the funds. The net liabilities will thus grow at a slower pace until the balancing ratio is once more greater than unity.

This mechanism is not sufficient to exclude depletion of the buffer funds. They are therefore allowed to borrow from the Swedish National Debt Office to bridge more extreme shocks. Such loans are counted as liabilities of the system and shall be repaid. ${ }^{6}$

The automatic balancing mechanism is an essential part of a financially independent and financially stable pension system. Its construction has been the most time-consuming element in the pension reform. ${ }^{7}$ Its design was decided by the parliament in the spring of 2001 as the final step of the Swedish pension reform.

\section{The transition to the new system}

Pensions systems fundamentally affect people's choices on how to organise their lives. A socially acceptable reform of a public pension system can therefore not be made overnight. People need time to adjust their work and saving patterns to new rules.

In Sweden, an extended transition period has been decided. People born before 1938 will have their entire pension from the old system, whereas people born in 1954 or later will have pensions determined solely by the new rules. The intermediate cohorts will have pensions based on both systems, with the share coming from the old system shrinking from 80 per cent for those born in 1938 to 5 per cent for those born in 1953 . 
There has been much debate about the incidence of the reform and the picture is quite complicated. The 15/30 rule has been said to favour women, since a period of part-time work did not affect the pension. On the other hand, people with steeper wage profiles, typically men, were favoured by the rule that the pension was determined by average income during the 15 best years. However, these analyses are of limited practical relevance. The fact of the matter is that people would not have received pensions according to the old rules, since the system would have broken down, sooner or later.

What is clear is that people born in the 1950s will have less than half of their working life to adjust to changes in their future pensions resulting from the new rules. Moreover, since the funded system was started in 1995, they will have smaller premium pensions than the younger cohorts. This means that the people most significantly affected by the reform are probably found in the cohorts from the 1950s. On the other hand, a more prolonged transition period would have put additional strains on the financial stability of the system (and/or the state budget). A balance had to be struck somewhere.

\section{Implications for public finances}

A central element of the reform is that the pension system will have to make do with a fixed percentage of the wage sum and has no further claims on the state. However, the state has not been able to cut the links in the future between the pension system and the state budget without making some concessions. Effectively, the share of tax revenues allocated to the pension system has been raised substantially. All in all, the central government gives up a net amount of approximately SEK50-60bn per year (equivalent to about $2.5-3$ per cent of GDP) as part of the pension reform. A major part of this is due to the fact that the guarantee pension is paid over the budget.

As a result, the central government is expected to run a deficit corresponding to $0.5-1$ per cent of GDP per year in the years ahead. This is more than offset by a surplus in the pension system, ie, the buffer funds and the premium funds will grow. This means that the consolidated public sector will record a significant surplus, at least until the big post-war cohorts retire ten to 15 years from now.

SEK50-60bn per year is lot of money for the central government. However, it should be compared to the costs that would have materialised if the pension system had not been reformed. Seen in this perspective, it can be interpreted as a price that has to be paid to make the pension system financially independent.

Moreover, this means that Sweden has begun to put the future costs of the public pension system on the budget already today. The fact that the state budget still is expected to record just a minor deficit - well below the expected growth rate of the economy and thus consistent with a falling debt-to-GDP ratio - can therefore be seen as a sign of long-term strength of Sweden's public finances. In Sweden, the price tag for pension reform has been set. In many other countries, the discussion about the existence of such a price tag has barely begun.

\section{Concluding comments}

The new Swedish pension system is based on political and economic compromises. However, given the starting point - a clearly unsustainable pay-as-you-go system — several important steps have been taken. Sweden 
now has a financially stable public pension system, which also gives stronger incentives for labour force participation. Moreover, the system is designed to be financially independent, in the sense that future financial imbalances are to be handled within the system, not by sending a bill to the state budget.

This does not exclude a decision at some time in the future to allocate additional resources to the pension system, for example, if the effects of the stabilising mechanism are deemed to be too severe. No political decision can irrevocably bind future policy makers. Still, now an active decision is required if more funds are to be transferred to the pension system, whereas in the old system it was the other way around. This may make a significant difference, in particular in situations where the state budget is already strained. Since the demographic transition in the decades ahead will affect public expenditures other than pensions, not least health care costs, this shift may prove quite valuable from the point of view of keeping public finances on a sustainable path.

\section{Acknowledgment}

The paper is based on a presentation prepared for the National Association of Pension Funds' Annual Conference and Exhibition, Birmingham, UK, 17-18th May, 2001. The author is grateful to Daniel Barr for comments on an earlier draft. The views expressed are those of the author and are not necessarily shared by the Swedish National Debt Office.

\section{References}

11 Technically, the payment is made by the employer, but effectively the money comes out of what otherwise would have been paid to the individual as earnings.

2 Not included in the figure is the National Social Insurance Board. It handles the administration of the pension system, for example, payments of pensions and the recording of individual pension rights.

3 The investment rules have been subject of debate, in particular, whether a 70 per cent share of equities is consistent with the target of low risk. The high ceiling reflects the view that equities are not so risky seen over a long-term investment horizon. The buffer funds started their activities on 1st January, 2001, but at the time of writing (June 2001) they have not yet disclosed their benchmark portfolios or internal investment guidelines.

4 For more information on PPM (also in English), see www.ppm.nu.

5 For more information on the Seventh AP Fund (also in English), see www.ap7.se.

6 There may also be an accelerator mechanism or some rebate system, which would be activated should the assets of the system exceed the liabilities by a sufficient amount. The design of such a mechanism is not decided, however.

7 It has also been contentious. In particular, the likelihood of the balancing mechanism being triggered has been hotly debated. This issue is beyond the scope of this paper, however.

\section{Further reading}

More detailed information in English on the Swedish pension reform and the new pension system can found in The Pension Reform in Sweden, published in June 1998 by the Ministry of Health and Social Affairs, and available on www.social.regeringen.se/inenglish/ publications/index.htm. 